\section{Revista de Literatura, História e Memória

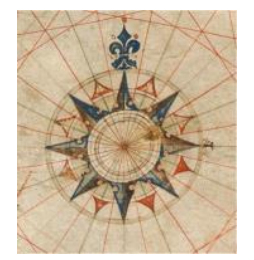 \\ Seção: Pesquisa em Letras no contexto Latino-americano e Literatura, Ensino e Cultura \\ ISSN 1983-1498 \\ VOL. 17 - No 30 - 2021 \\ U N I O E S T E / CA S C A V E L - p. 270-286}

\title{
"UM MAL QUE ESPREITA FEITO UMA JARARACA NA MOITA": CORONELISMO, VIOLÊNCIA E MEDO EM $O$ TRONCO, DE BERNARDO ÉLIS
}

"An evil that lurks like a viper in the bushes": coronelismo, violence and fear in $O$ tronco, by Bernardo Élis

\author{
Leonardo José Rodrigues ${ }^{1}$ \\ Ewerton de Freitas Ignácio ${ }^{2}$
}

RESUMO: Este trabalho tem como proposta realizar uma análise do romance $O$ tronco (1956), do escritor goiano Bernardo Élis, buscando empreender os modos como o coronelismo, a violência e o medo são tratados no romance. Baseando-nos na categoria da violência, elemento constituinte da narrativa enfocada, procuramos investigar como ela se instaura como elemento intrínseco ao enredo do romance analisado, afetando as personagens, o enredo e o texto, ao mesmo tempo em que lhe plasma o conteúdo e a forma, buscando, ainda, evidenciar que se tem, no romance em tela, a cristalização de episódios violentos, pautados sob a égide da intolerância, associados ao momento histórico goiano retratado.

PALAVRAS-CHAVE: Violência; Coronelismo; Literatura goiana.

ABSTRACT: This work proposes an analysis of the novel $O$ tronco (1956), by Bernardo Élis, seeking to understand the ways in which coronelismo, violence and fear are treated in the novel. Based on the category of violence, a constituent element of the focused narrative, we investigate how it establishes itself as an intrinsic element of the analyzed novel, affecting the characters, the storyline and the text at the same time in its content and form, seeking to further evidence that we have, in this novel of Bernardo Élis, the crystallization of violent episodes, ruled under the aegis of intolerance, associated with the historical moment in Goiás that was portrayed by the author. KEYWORDS: Violence; Coronelismo; Literature of Goiás.

\section{INTRODUÇÃO}

A literatura de feição regionalista produzida em terras goianas encontra um representante digno de nota em Bernardo Élis (1915-1997), que se tornou um dos escritores goianos mais conhecidos no Brasil, em virtude, principalmente, do seu modo peculiar de escrever, ao retratar de forma bastante lírica e contundente o Goiás do início do século XX, adicionando marcas da oralidade do povo goiano em suas obras. De toda a sua produção literária, merece destaque $O$ tronco, publicado inicialmente em 1956, cujo enredo apresenta

\footnotetext{
${ }^{1}$ Mestre em Ciências Sociais e Humanidades, pelo Programa de Pós-Graduação em Territórios e Expressões Culturais do Cerrado - TECCER (UEG). Licenciado em Letras - Português e Inglês e suas respectivas literaturas pela Universidade Estadual de Goiás - Campus Anápolis.

${ }^{2}$ Professor titular da Universidade Estadual de Goiás/Anápolis, onde atua junto ao PPGSS POSLLI (Língua, Literatura e Interculturalidade) e junto ao PPGSS TECCER (Territórios e Expressões Culturais do Cerrado).
} 
como pano de fundo a luta entre grupos políticos rivais que acabou por eclodir no norte goiano, dando ensejo a um capítulo sangrento da história de Goiás, o qual é recuperado nesse romance do criador de Veranico de janeiro.

Presente na sociedade desde os primórdios da humanidade, a violência se manifesta de diferentes maneiras em diferentes contextos. Para Nilo Odalia (1983, p. 13), "viver em sociedade foi sempre um viver violento", uma vez que a violência está presente no meio social desde o surgimento da humanidade e, em razão disso, está incorporada diretamente à vivência humana individual e coletiva. Nesse sentido, a literatura configura-se como uma das expressões em que crimes perpetrados com violência e crueldade se tornam material narrado, de modo a reconstituir a história de pessoas e de grupos sociais de determinado local.

É desse modo que Bernardo Élis encontra, no plano da realidade, material com o qual erige a massa verbal de sua narrativa, em cujas páginas, a violência se revela como algo intrínseco tanto ao contexto histórico e político quanto ao contexto mais restrito das interações pessoais, de modo que se notam correlações entre contexto histórico-político e social, espaços narrativos e personagens, todos representados como elementos permeados por relações de crueldade e violência.

Interessa-nos, portanto, neste trabalho, averiguar como se processam as figurações da violência em $O$ tronco, entendidas como as maneiras pelas quais a violência acaba por balizar as vivências humanas, impondo-lhes limites, cerceamentos, medo, dor e morte. Para tanto, o presente trabalho é dividido em duas seções principais. Na primeira, apresentamos definições para os termos violência e coronelismo, buscando discutir as relações entre esses conceitos no sertão goiano. Na segunda seção, empreendemos uma leitura dos modos pelos quais esses termos são representados no contexto narrativo do romance em tela, buscando relacioná-los ao momento histórico goiano retratado.

\section{CORONELISMO E VIOLÊNCIA EM GOIÁS}

Segundo um dos primeiros estudiosos que tratam sobre a violência, o sociólogo Johan Galtung (1969), a violência deveria ser conceituada de forma que abarque todas as suas dimensões, podendo-se afirmar que ela é " a causa da diferença entre o potencial e o real, entre o que poderia ser e o que é. Violência é o que aumenta a distância entre o potencial e o real, e o que impede a diminuição dessa distância” (GALTUNG, 1969, p. 168, grifo do autor, tradução nossa). Nesse sentido, para o estudioso, esse fenômeno ocorre quando algumas condições impedem alguém de alcançar seu nível potencial máximo, assim como, quando 
essas condições não possibilitam a diminuição da distância entre o nível real e o nível potencial. No entendimento do autor, o nível potencial das realizações humanas é aquele que é conseguido por meio de determinados conhecimentos e/ou recursos. Portanto, a violência acontece caso esses conhecimentos ou recursos estejam apenas nas mãos de alguns, limitando o desenvolvimento potencial de outros.

Nilo Odalia, sociólogo brasileiro, também procura definir o termo, de modo que, em seu livro O que é Violência (1983), propõe que a violência "nos despoja de alguma coisa, de nossas vidas, de nossos direitos como pessoas, como cidadãos. A violência nos impede não apenas de ser o que gostaríamos de ser, mas fundamentalmente de nos realizar como homens" (1983, p. 87). Assim, a violência é vista como uma forma de privação que, em consonância com o conceito de Galtung (1969), impede os seres humanos de se desenvolverem plenamente, de atingirem suas potencialidades.

Para ambos os autores, a violência acontece de diferentes formas e consiste em dimensões distintas. O sociólogo norueguês apresenta algumas distinções que podem auxiliarnos a caracterizar a violência. A distinção que vale a pena mencionar neste trabalho é a verificada entre a violência física, aquela que atinge diretamente o corpo, sob a qual o ser humano é machucado fisicamente, e a violência psicológica, a que atinge a alma, que inclui mentiras, lavagem cerebral, doutrinação de todo tipo, entre outras coisas que servem para diminuir as potencialidades mentais (GALTUNG, 1969, p. 169). Já o brasileiro propõe divisões ao ato violento pelo modo em que ele acontece na sociedade, existindo, além da violência física, mais explícita, meios em que ela se manifesta de forma implícita, como por meio do temor e do medo (ODALIA, 1983).

A violência está diretamente incorporada à vida das pessoas em sociedade, uma vez que o ser humano sempre teve sua vivência pautada por questões relacionadas, de alguma forma, com a violência: desde atos menos perceptíveis, como a luta pela sobrevivência, que remonta aos primeiros humanoides, até às antigas e contemporâneas lutas pelo poder e por status social, sem falar na opressão sofrida pelas classes menos favorecidas e nas privações que o homem sofre no decorrer de sua vida social, além de atos mais explícitos, como roubos e assassinatos. Nessa perspectiva histórica, a violência caracteriza-se como uma espécie de elo entre lugares e épocas distintas.

Hannah Arendt (1985), ao tratar sobre esse conceito, procura relacioná-lo à noção de poder, o que aproxima, de certo modo, suas considerações com as dos autores já citados nesta seção, uma vez que, para ambos, a violência acontece em uma situação em que determinados indivíduos exercem seu poder sobre outros, cerceando-os e subjugando-os. Nesse sentido, a 
estudiosa aponta para o fato de que é normal que violência e poder se intercambiem na sociedade, de modo que "a violência [possa ser vista] como a última opção para que a estrutura de poder seja mantida intacta contra os vários tipos de desafios - do inimigo estrangeiro, do criminoso local - parece realmente ser a violência o pré-requisito do poder, e o poder nada mais que uma fachada" (ARENDT, 1985, p. 29).

Vale ressaltar que Arendt (1985, p. 30) salienta que, nas competições de violência contra violência, o governo sempre leva vantagem, desde que permaneça "intacta a estrutura de poder do governo - isto é, enquanto forem obedecidas as ordens, e o exército ou a força policial estiverem dispostos a usar as suas armas". Caso contrário, a revolta deixa de ser controlada e as armas trocam de mão. Embora não seja o contexto a que Arendt se refere, essa constatação é verificada na narrativa de Élis, uma vez que as bases de poder de Goiás, principalmente na região da Vila do Duro, na época, não eram bem definidas, de modo que coronéis do Norte, representantes de um poder privado fortalecido, e do Sul, representantes de um poder público mal organizado, batalhavam pelo controle do estado.

Além disso, a estudiosa salienta que a violência, ao contrário do poder que, ao ser legitimado, não precisa de justificativa, tem um caráter instrumental, o que significa que ela se manifesta por meio de instrumentos que servem para justificá-la: "a legitimidade, quando desafiada, baseia-se em um apelo ao passado, enquanto a justificativa diz respeito a um fim que se encontra no futuro" (ARENDT, 1985, p. 33). Na obra de Bernardo Élis, tem-se uma narrativa em que suas personagens lançam mão da violência por conta de diferentes motivações e justificativas, as quais refletem os valores da época em que prezavam a cultura da valentia (OLIVEIRA, 2015).

No que diz respeito ao contexto narrativo de $O$ tronco, a violência esteve presente no sertão goiano desde que esse espaço foi entendido como tal, passando a se tornar objeto de disputas travadas, inicialmente, entre bandeirantes e indígenas e, posteriormente, entre chefes políticos, os coronéis locais (PALACÍN; MORAES, 1994). O estado de Goiás, sobretudo durante o século XIX e até meados do século XX, teve sua imagem relacionada ao atraso e à barbárie. Mais que isso, Goiás era um local perigoso, cheio de ameaças e violências; um lugar onde eram "frequentes ataques indígenas e de jagunços que aterrorizavam fazendas e vilarejos" (DUTRA E SILVA; MOURA; CAMPOS, 2015, p. 239). Para os autores, nesse cenário de dificuldades,

os senhores de terra e de gado em Goiás assumem, nessa análise, significativo valor interpretativo, considerando as proporções continentais do território brasileiro e as articulações entre o império brasileiro e as elites 
locais, como forma de garantir a integridade territorial e a autonomia fiscal na fronteira (DUTRA E SILVA; MOURA; CAMPOS, 2015, p. 239).

Nessa perspectiva, os coronéis, os quais faziam parte das elites locais, passam a assumir o papel administrador e controlador que deveria ser do Estado. Assim, começam a exercer os poderes Executivo, Legislativo e Judiciário sob o pretexto de estarem defendendo os interesses do Estado, quando, na verdade, os interesses defendidos eram simplesmente um apanhado de vontades privadas.

No que diz respeito ao termo coronelismo propriamente dito, observa-se que se trata de uma expressão utilizada para definir uma estrutura de poder complexa, que se inicia na figura do gestor municipal, o coronel, e apresenta caracteres secundários, como mandonismo, apadrinhamento, fraude eleitoral, centralização e desorganização do poder público (JANOTI, 1992). Para Leal, o coronelismo se define como o

resultado da superposição de formas desenvolvidas do regime representativo a uma estrutura econômica e social inadequada. Não é, pois, mera sobrevivência do poder privado, cuja hipertrofia constituiu fenômeno típico de nossa história colonial. É antes uma forma peculiar de manifestação do poder privado, ou seja, uma adaptação em virtude da qual os resíduos do nosso antigo e exorbitante poder privado têm conseguido coexistir com um regime político de extensa base representativa (LEAL, 2012, p. 22).

Por esse ângulo, o coronelismo liga-se à manutenção da dominação do poder privado, concentrado primordialmente nas mãos dos proprietários de terra cuja ancestralidade, na maioria dos casos, remonta ao período colonial, plasmando todo um sistema baseado na troca de favores, por meio de acordos tácitos e não escritos cujos desdobramentos práticos fazem com que o poder privado e o poder político se coadunem.

Francisco Itami Campos (1987), sobre a configuração do coronelismo em Goiás, afirma que, por meio de um pacto entre os poderes políticos e os coronéis, esse sistema foi se institucionalizando, de modo a criar o estabelecimento de alianças, uma vez que a base do compromisso coronelista era, antes de tudo, a reciprocidade (CAMPOS, 1987). É interessante notar que, no contexto narrativo de $O$ tronco, é justamente o rompimento dessa relação recíproca entre o poder político e os coronéis que resulta nos acontecimentos narrados pelo romancista goiano.

Entretanto, apesar do intuito da política coronelista, pelo menos na época da sua concepção, de reciprocidade entre os poderes público e privado, os coronéis, com o tempo, assumiram o controle de determinadas regiões, tornando-se verdadeiros governantes, e isso 
resultou no desligamento desse pacto inicial. Como já mencionado, o contexto político e econômico do estado era propício para que isso acontecesse, já que por conta de "um Estado fraco e inoperante, os senhores de gado executavam essas funções e agiam como autoridade, os donos do poder na fronteira" (DUTRA E SILVA; MOURA; CAMPOS, 2015, p. 240).

Para Oliveira (2012), a consequência disso foi a institucionalização do poder desses chefes locais, os quais submetiam as pessoas do sertão às suas vontades pessoais. Dessa forma, pode-se compreender o coronelismo como um sistema propício para a recorrência de momentos violentos, pelo fato de a violência ser, nesse contexto, objeto utilizado tanto pelos coronéis nas suas disputas pelo poder local, no uso da força e da intimidação contra inimigos políticos e contra a população como um todo, na busca pela manutenção do poder e pela satisfação de suas vontades, como pelos jagunços do coronel, com o intuito de defender os interesses do patrão.

Além desses, tinha a força policial que, sendo representante do poder público nos locais em que o poder privado do coronel era praticamente ilimitado, tentava, por meio da violência e da intimidação, fazer com que a Lei fosse seguida e a ordem instaurada. Para Oliveira (2012, p. 27), a força policial era "a expressão política e institucionalizada mais contundente da violência em Goiás".

Por fim, vale ressaltar que, se durante o coronelismo a violência esteve inserida diretamente na vivência dos goianos, por causa das possibilidades que contribuíam para que ela fosse usada pelas forças que atuavam em território goiano, é no período em que o Estado busca retirar o poder das mãos dos coronéis que a violência mais se manifesta. "O processo lento e ainda incompleto de monopolização da violência pelo Estado de Goiás produziu conflitos sangrentos" (OLIVEIRA, 2012, p. 27).

É nesse momento que a narrativa de $O$ tronco se insere. Ainda segundo Oliveira (2012), o contexto dos fatos que inspiraram Élis a criar seu romance constitui um período no qual os proprietários de terras, que também eram proprietários de gados e de homens, eram fortes o suficiente para desencadear uma guerra contra o Estado. Também, nesse período é que os sertanejos, no sentido mais aberto da expressão, têm seu sangue derramado nas terras do sertão.

\section{CORONELISMO, VIOLÊNCIA E MEDO EM O TRONCO}

Narra-se, em $O$ tronco, uma luta travada entre os jagunços do coronel Pedro Melo, grande senhor de terras da região da Vila do Duro, e as forças militares do governo estadual 
de Goiás. Tal luta foi iniciada por conta de uma desavença entre Artur Melo, deputado e filho do coronel Pedro Melo, e os representantes do governo do estado na vila, Vicente Lemes e o juiz Valério Ferreira. De um lado, nessa disputa de interesse, estão os detentores do poder local, cuja autoridade se faz por meio do medo e da intimidação, e, do outro, estão aqueles que buscavam o estabelecimento da lei e da justiça.

Quando o coletor estadual, Vicente Lemes, e o juiz, Valério Ferreira, impugnam o inventário da viúva de Clemente Chapadense, que tinha como advogado Artur Melo, por notarem algumas irregularidades, como omissão de bens, os Melos invadem a vila do Duro, numa demonstração violenta de força, e obrigam o juiz a aceitar o documento. Nesse ínterim, o governo do estado, já afastado politicamente do coronel Pedro Melo, envia forças militares para o restabelecimento da ordem na região, ao passo que Pedro e o filho Artur reúnem forças no norte de Goiás e na Bahia, o que resulta em uma guerra em cujo intercurso morrem, dentre jagunços, moradores e soldados, nove prisioneiros que estavam amarrados ao tronco.

Esse fato, narrado por Élis, tem como inspiração um acontecimento marcante da história goiana, que ficou conhecido como a Chacina de São José do Duro, ocorrida em 1919 no norte do estado, onde hoje é o município de Dianópolis, no Tocantins. A chacina foi resultado de disputas de poder entre duas grandes oligarquias goianas da época, quais sejam os Wolneys, coronéis do norte de Goiás, e os Caiados, coronéis do sul do estado, os quais eram os detentores do poder público institucionalizado. Em se tratando dos fatos históricos e dos acontecimentos narrados por Bernardo Élis, pouco se distanciam, embora, como se pode constatar, o romancista tenha trocado os reais nomes das principais personalidades que figuram como personagens do romance.

A vida dessas e de outras personagens que povoam o universo ficcional d' $O$ tronco era pautada por códigos de conduta não escritos e as relações pessoais se davam, quase sempre, por meio da opressão que o povo menos favorecido sofria nas mãos dos grandes coronéis que comandavam o sertão. Marinalva Barroso, em sua recente dissertação “Transcriação narrativa do romance $O$ tronco, de Bernardo Élis, e suas variações discursivas”, salienta que "Bernardo Élis reinventa a realidade regional, compondo quadros pelos quais reconstrói a mencionada opressão ao povo goiano menos favorecido" (BARROSO, 2018, p. 14); e não apenas isso, ele também desvela as relações pessoais do homem goiano que, além da opressão, sofria com a violência perpetrada pelos coronéis, seus jagunços e até mesmo pela força policial da época.

No romance em tela, há características próprias da escrita literária de Élis, marcadas pela experimentação semântica que o autor faz com o uso de algumas palavras e expressões, 
pelo retrato poético do cenário em que a narrativa se passa e pela incorporação, no texto, das manifestações linguísticas do sertanejo. Todos esses aspectos relacionados contribuem para percebermos como se dá a representação da violência no romance de Élis, reconhecendo também as diferentes figurações que esse elemento adquire nessa obra.

Ações que se deixam ler como violentas se realizam de diferentes maneiras na sociedade e, no sertão goiano retratado por Bernardo Élis, elas também adquirem distintas características que permitem diferenciá-las pela maneira como acontecem e são narradas na obra. Nesse aspecto, nota-se, no romance, uma intensa ligação entre tais ações e o medo, o qual, segundo Odalia (1983), também é uma forma de manifestação da violência. Além disso, alguns atos violentos acontecem de forma abrupta, sorrateiramente, de modo que, quando a vítima se dá conta, não consegue mais se desvencilhar do perigo.

Em determinado momento da narrativa, assim que o bando de Artur Melo chega na vila do Duro para vingar-se do assassinato da morte do coronel Pedro Melo, tem-se uma descrição que, por meio de sua leitura, se evidencia a maneira pela qual o autor goiano se utiliza dos artifícios que tem para construir sua narrativa tendo como mote a violência:

\begin{abstract}
um ou outro urubu que ficava em riba da cumeeira ou alguns bem-te-vis que davam seus mergulhos, pegando as mariposas voejantes sobre os cupins. Nem as almas-de-gato piavam. A erva crescia com viço extraordinário. Há poucos dias, quando não se notava o mato que chegava agora a esconder um boi. O caruru-de-porco, o fedegoso brabo, a erva-de-santa-maria cresciam com uma pujança de feitiço. Havia no ar um cheiro de verde, de coisa apodrecida, de semente germinando (ÉLIS, 1987, p. 210).
\end{abstract}

$\mathrm{Na}$ medida em que o narrador descreve o cenário, criando um retrato que tem a função de situar o leitor e, até mesmo, imergi-lo naquele ambiente, a inquietação, causada pelo ataque iminente do coronel Artur, vai sendo introduzida lentamente a partir das características que o narrador atribui para aquele lugar: silencioso, onde "nem as almas-de-gato piavam", onde só podia ser notado o movimento das ervas que cresciam e do "cheiro de verde, de coisa apodrecida, de semente germinando" que pairava sobre o ar. Trata-se de elementos que gradativamente tomam conta do ambiente, da mesma forma que a tão temível comitiva de jagunços se aproximava.

Inicialmente, percebe-se que a violência física é retratada em $O$ tronco por meio de cenas bastante explícitas. Depois que Artur Melo e seus correligionários começam a marchar em direção à vila para cumprir seus planos de vingança, a polícia, no intuito de parar Artur, decide prender boa parte da família do coronel no tronco, um instrumento de tortura utilizado 
na época da escravidão no Brasil. Ao se sentirem presos e acuados pelas tropas de Artur, alguns soldados resolvem matar todos, impiedosamente. São as cenas mais marcantes de todo o romance:

a Winchester de Mané Vitô roncou sinistra, até engasgar. Gritos e gemidos encheram a casa, de par com a fumaceira. Nisso, do escuro do quarto, o rosto de Damião de Bastos se destacou, cresceu para o soldado Mané Vitô. Damião de Bastos tinha cara ruim e fora o único prisioneiro que jamais pediu coisa alguma durante a prisão. Aquela cara máscula cresceu no escuro do quarto, contraiu-se e pegou a chorar feito um menino!

- Me mata premero. Num quero ver meus filhos morrer na minha frente. Me mata!

Rapidamente Mané Vitô encheu a carabina e novas detonações retumbaram pelo velho sobrado (ÉLIS, 1987, p. 217).

A súplica do pai pela vida dos filhos é marcante, mas nem por isso o soldado se mostra mais compassivo. Só quando Mané Vitô percebe o que fez é que se mostra "trêmulo, desfigurado, olhando para o quarto do tronco [...] como se dali viesse um fantasma pronto para matá-lo" (p. 218). O fantasma que o assombraria pelo resto da narrativa seria o fantasma da culpa e do medo. Essas mortes não ficam presas na memória apenas desse soldado. $\mathrm{O}$ protagonista, Vicente Lemes, e muitos outros compartilham, ao final da narrativa, a culpa coletiva que se apoderou de muitos deles em razão da matança acontecida na vila.

Antônio Cândido (1976) salienta que é o modo pelo qual o autor dirige o olhar do leitor para as personagens que as torna sempre seres inesgotáveis e insondáveis. Em O tronco, as personagens são sempre multifacetadas, capazes de reproduzir extremos. No trecho supracitado, pode-se perceber a complexidade de Damião de Bastos, que, mesmo sendo uma personagem cuja caracterização o aproxima do estereótipo de macheza e bravura, tem um rompante em que se pode vislumbrar sua fragilidade, sua sensibilidade.

O assassinato de Hugo Melo é outro marcante momento que mostra a face terrível da violência que assola o sertão goiano em $O$ tronco. Estando entre os parentes presos de Artur no tronco, Hugo Melo é poupado da morte por um tempo. No entanto, quando os soldados já não têm mais esperanças de ganhar a luta, decidem matá-lo para punir Artur e para mostrarem-se corajosos, já que, para muitos dos sertanejos, a violência é uma forma de demonstrar coragem (IGNÁCIO, 2010). A morte de Hugo é carregada de sentimentalismo:

Freitas se aproximou e, num gesto rápido, meteu um tiro de Comblain no peito de Hugo, que amoleceu nas mãos de Severo e se amontoou no chão batido da salinha baixa, de paredes esburacadas, feito um boneco de trapo.

No chão, Hugo estertorava, gemendo: [...] 
— Está doendo muito, acaba de me matar! (ÉLIS, 1987, p. 251).

Para Mendes (2015), um romance histórico não é uma mera representação de uma época, mas uma obra literária composta por elementos formais que podem desvelar os caracteres mais estilísticos da obra. No romance de Bernardo Élis, podemos ver que um dos caracteres estilísticos utilizados para tratar a violência são as comparações. Nesse trecho, o autor compara Hugo Melo a um boneco de trapo que, já quase sem vida, cai no chão batido, gemendo.

Nesse aspecto, ao fazer uma breve retrospectiva histórica da violência, Odalia (1983) assevera que não apenas a violência física esteve presente na história, como também o medo poderia ser suscitado, em determinados momentos, por atitudes em que a violência ocorria de forma velada, tal como o temor exacerbado que o homem medieval tinha de não conseguir ascender aos céus após sua morte.

Em $O$ tronco, a violência se manifesta também, em diversos momentos, por meio do medo. Os moradores da vila do Duro viviam assombrados com a presença do coronel Pedro Melo, de seu filho Artur e de seus desmandos. O medo está presente praticamente do início ao fim da narrativa, e a intensidade dele vai se tornando cada vez maior no desenrolar da história. Inicialmente, presenciamos o momento em que o juiz indicado para investigar um assassinato cometido pelo coronel Pedro Melo, Dr. Hermínio, assustado com os rumos que o julgamento está levando, desiste de condenar o coronel por medo:

a testemunha seguinte era Resto-de-Onça, capanga de Pedro Melo, um dos que participaram diretamente da morte de Vigilato e que deveria estar apontado como réu. Ao assentar-se no tamborete, em frente ao juiz, alguma coisa tombou ruidosamente no chão. Dr. Hermínio vagarosamente moveu o vasto corpanzil, tirou os óculos que só permitiam ver próximo, e arregalou os olhos. No chão estava a imensa garrucha de Resto-de-Onça [...] Dr. Hermínio compreendeu a impossibilidade de apurar ali qualquer coisa. Os Melos eram os donos de tudo (ÉLIS, 1987, p. 17).

Em relação à instância narrativa da obra, constata-se que o narrador de $O$ tronco se encaixa na segunda concepção de "doador da narrativa” proposta por Roland Barthes, a qual "faz do narrador uma espécie de consciência total, aparentemente impessoal, que emite a história do ponto de vista superior, o de Deus" (BARTHES, 2011, p. 49-50). Esse tipo de narrador contribui para que o leitor tenha uma visão mais geral dos eventos narrados e, aqui, o narrador empenha-se em utilizar bastantes advérbios de modo, como "diretamente", "ruidosamente" e "vagarosamente", a fim de explicitar ainda mais a forma como os eventos 
aconteceram. Observe-se que esse grande uso de advérbios para construir cenas mais ricas em detalhes é uma das características mais marcantes da escrita de Élis, tanto no romance analisado quanto no restante de sua produção.

Torna-se patente, no trecho apresentado, que o medo está presente nas relações pessoais dos moradores (e visitantes, como o caso do juiz) do Duro e que suas vivências são pautadas, dentre outras coisas, pelo temor que sentem das personagens consideradas portadoras da violência, quais sejam o coronel, os jagunços e a força policial. Por um lado, os jagunços eram temíveis, pois eram quem cuidavam dos interesses do coronel. "Jagunço é bicho custoso de morrer. Para tiro ofender jagunço, só se ele estiver com os pés no ar, por riba de uma cerca, passando numa ponte" (ÉLIS, 1987, p. 187-188). Por outro, a força policial "não merecia confiança" (p. 142), pois era composta por "um bando de facínoras" (p. 142).

A memória coletiva dos moradores da vila do Duro é também uma das responsáveis pela propagação do medo em $O$ tronco, visto que, em muitos momentos, o passado assombra as personagens em virtude da possibilidade de acontecer no Duro o que já havia acontecido antes em outras localidades. São lembranças de episódios violentos outrora acontecidos, marcados no imaginário das personagens.

Os Melos é que permaneciam ausentes, na Grota, onde diziam pululavam jagunços e facínoras [...]. No casarão de Dona Benedita, contavam casos de Roberto Dorado, Abílio Batata, o assalto de Pedro Afonso, o ataque de Porto Nacional. Falavam de Enéias, a família dele trucidada por jagunços, a mulher grávida defendendo a barriga donde tiraram o menino vivo (ÉLIS, 1987, p. 75-76).

Vale lembrar que o ato truculento observado nesse excerto ainda é a noção de violência psicológica tratada por Galtung (1969) e comentada por Odalia (1983), qual seja a que atinge a alma, embora se trate de um ato violento que permeia a memória coletiva, configurando lembranças compartilhadas por meio de cuja irrupção as personagens se tornam mais desesperançadas. Em outro trecho, as memórias comuns dizem respeito ao tratamento que os jagunços davam às mulheres que encontravam em meio às lutas que travavam:

em Boa Vista, os jagunços faziam coisas horríveis. Dez, vinte homens se servindo de uma mulher, na vista do marido, dos filhos, dos pais. De uma, contavam, puseram ela nua e fazendo tanto pecado, mas tanto, que quando os bundões foram embora essa coitada se atirou no rio e morreu de vergonha (ÉLIS, 1987, p. 144-145).

É interessante notar que, nos trechos em que são narradas essas memórias, o narrador 
deixa claro que as histórias foram contadas de uma pessoa para outra, mas nem por isso elas produzem uma reação menos temerosa nas personagens.

Já no final da narrativa, o medo sentido pelas personagens atinge níveis altíssimos. Mendes de Assis, um dos tenentes encarregados de defender a vila do Duro durante o ataque de Artur e seu pessoal, logo nas primeiras horas de combate, "desfiando o rosário [...] ordenou a evacuação do quartel, mas o tiroteio era tal que ninguém se encorajava a sair. $\mathrm{O}$ medo agarrava o oficial, pintava-lhe os jagunços chegando, o amarrando num pau e picando vivo, aos tiquinhos" (ÉLIS, 1987, p. 216). Há nesse trecho a personificação do medo, o qual adquire habilidades humanas e "agarra" a personagem e faz com que ela veja cenas do que poderia ser seu futuro.

Em determinado momento da narrativa, uma metáfora insuspeita é tecida em relação à morte marcante e triste da criança Brasica, amiga de Alice, filha de Vicente Lemes, a qual é a primeira pessoa que conta ao protagonista sobre a morte da menina, que faleceu ao ser atingida por uma bala enquanto a Vila do Duro recebia as investidas das tropas de Arthur. Antes de fugir, Vicente decide ir ver a menina, depositada em um quarto, e é nesse momento que o narrador se vale de uma comparação entre a violência sofrida pela menininha inocente e uma jararaca:

Vicente quis ver Brasica, no quarto perto da cozinha. Bem dizer: era um defuntinho. O nariz azulado, muito afilado, os beicinhos roxos e o diabo do sangue sempre minando. Coitadinha! Tão bonitinha, tão viva, tão alegre de sua pequena vida. Ainda outro dia brincando por baixo dos cacaueiros, sem nunca pensar no mal que a esperava feito uma jararaca na moita (ÉLIS, 1987, p. 246).

Nesse trecho, percebe-se quão isenta de comiseração é a guerra travada na vila. Brasica, horas antes, garotinha feliz e plena em sua infância, mal sabia que a violência, feito uma jararaca à espreita, faria dela mais uma vítima. Esse não é, contudo, o único momento da narrativa em que a violência se mostra traiçoeira, à espreita, sem que as personagens percebam o perigo que correm.

Logo no início do romance, Vigilato, sobrinho do coronel Pedro Melo, indispõe-se com o tio, o todo-poderoso da Vila do Duro. Após muitas desavenças e implicâncias, Pedro Melo, à noite, chama alguns homens de sua confiança e dão um fim em Vigilato, sorrateiramente no breu da noite. O sobrinho vinha no Largo na vila, cantarolando modinhas muito bêbado e, com sua voz pastosa, 
Tito e Resto-de-Onça, mandou em casa do genro e sobrinho Tozão buscar o capanga Aleixo, tudo em silêncio, na ponta dos pés, cochicho nos ouvidos. Muito de sutil os três homens esperaram o bêbado; e quando ele encostou na calçadona alta do tio para soltar a sua cantiga, foi um vup e ram; meteramlhe o porrete no piolho [...] a voz de Vigilato esbarrou num baque, a mó que engasgada, deixando o breu da noite ainda mais escuro (ÉLIS, 1987, p. 12).

A morte de Vigilato também pode ser vista como semelhante à morte de Brasica. A violência afligida ao rapaz se desenvolve sorrateiramente e ele, enquanto objeto a ser violentado, mal fazia ideia do perigo que estava correndo antes de, de fato, ser assassinado. É como uma jararaca que, na moita, espera o momento certo para fazer mais uma vítima, e o narrador contribui com a escolha de palavras para fazer com que os homens pareçam mais peçonhentos e letais, mais sutis e silenciosos o possível. Interessante também ressaltar que a alegria das músicas que Vigilato cantava, bêbado, à noite, "modificava a pasmaceira estagnada do lugarejo" (ÉLIS, 1987, p. 12) e, instantaneamente, quando ele morre, "o breu da noite" fica mais escuro.

Essa cena continua com um trecho marcante que demonstra a sensibilidade e o talento de Élis para escrever e, ao mesmo tempo, descrever as situações de forma completamente visuais e simbólicas. Os assassinos do moço acendem uma "lanterna furta-fogo", emitindo uma luz avermelhada no meio de todo o breu que se instalou no Largo, e carregam o morto, sendo possível ver "no Largo negro, uma mancha vermelha que se movia confusa e incerta" (ÉLIS, 1987, p. 12). É possível facilmente visualizar a mancha vermelha que se move na escuridão e relacioná-la ao sangue confuso e incerto do garoto assassinado de forma tão brutal, configurando o que Tomachévski (1978) conceitua como "motivação caracterizadora homóloga", ou seja, quando se nota uma relação de homologia entre o espaço retratado e as personagens que nele agem.

É de forma silenciosa e brutal que outra personagem, Clemente Chapadense, morre durante a narrativa de $O$ tronco. Sofrendo com ameaças de aliados de Artur Melo, Clemente vai ao cartório pedir proteção ao juiz Valério Ferreira. Na volta para casa, é morto de forma covarde e sorrateira. Nesse trecho do romance, o autor vale-se de uma elipse para deixar o acontecimento suspenso, uma vez que não é narrada, de modo explícito, a morte da personagem, a qual é confirmada pelos acontecimentos subsequentes. Para Ginzburg (2012, p. 30 ), "em textos que apresentam configurações de violência, no século XX, duas figuras de linguagem tendem a ser recorrentes [...] essas figuras são a hipérbole e a elipse”. Ainda segundo o autor, essas figuras representam extremos. O romance de Élis é um desses textos em que essas figuras estão bastante presentes e fazem parte dos artifícios do autor para criar 
meios de produzir estranhamento e assombro mediante o retrato de ações violentas.

No caso da morte de Clemente, o assassinato em si foi omitido, mas o fato, sem dúvidas, aconteceu. No dia seguinte, é o próprio Artur quem chega ao cartório para pedir por justiça:

— Onde estão as autoridades desta terra, Seu Escrivão?

- Por que pergunta, Seu Coronel? - respondeu solícito o funcionário.

- Porque mataram um homem, meu amigo Clemente Chapadense, e nenhuma autoridade compareceu ao local para o auto de corpo de delito. Onde estão as autoridades? (ÉLIS, 1987, p. 24).

Mais adiante, algumas pessoas discutem a respeito de como Clemente poderia ter morrido e alguém propõe que o teriam matado de tocaia, o que nos reporta à observação de Oliveira (2012, p. 42), segundo a qual, "a tradição de confronto violento em Goiás era a tocaia, herdada dos bandeirantes: o ataque surpresa, e se possível, a aniquilação total do inimigo". Essa afirmação corrobora a configuração da violência como algo também tributário do silêncio e da espera calculista. Nota-se, ainda a esse respeito, que Norato é outra personagem que sofre com esse tipo de brutalidade. Tendo se indisposto com gente ligada a Artur, "o que acharam de fazer foi matar o coitadinho de tocaia" (ÉLIS, 1987, p. 46).

Por fim, nessa narrativa do contista de "A enxada", a violência também adquire um caráter democrático. Não apenas pobres e jagunços morrem nas mãos dos coronéis e da polícia, mas também pessoas importantes, tal como o próprio coronel Pedro Melo que foi surpreendido pela polícia enquanto cavalgava pela fazenda e, não tendo como reagir, homiziou-se com Mulato, seu ajudante, no canavial:

- Não me mate — dizia o velho de mãos erguidas. Como respostas coronhadas desceram-lhe na cabeça, prostando-o na terra fofa e úmida do canavial.

- Me acorde, meu filho. - Um tiro ecoou. O velho punha-se de quatro pés, tentando levantar.

- Estou aqui meu patrão - gritou Mulato, mas uma coronhada abriu-lhe o crânio. Uma baioneta na ponta do cano da Comblain meteu-se-lhe no peito, espetando-o no chão podre. Daniel embebeu o refle no ventre do velho. Gabriel tirou um punhal e o socou no ventre do homem caído (ÉLIS, 1987, p. 121).

Não obstante a rendição e a súplica do coronel, ele é assassinado e roubado pelos homens da polícia, que, de acordo com o narrador, eram instigados pelo barulho dos tiros, pela imagem do sangue, pelo toque renitente das cornetas, tal "como acontece aos onceiros" (ÉLIS, 1987, p. 122). 
Como se pode constatar pela leitura do trecho apresentado, a violência retratada na massa verbal de $O$ tronco, seja a perpetrada pelas forças militares do governo estadual seja a cometida pelos jagunços do coronel, plasma um espaço de temor que, se num primeiro momento atinge os mais fracos, ao final acaba por atingir aos mais fortes, aos que detinham o poder local, deixando claro que tal brutalidade, que comumente vitima os mais indefesos, também pode imolar os mais fortes, a exemplo do que também ocorre no contexto narrativo do romance Chapadão do bugre (1966), de Mário Palmério, em que o coronel Américo Barbosa, a despeito de todo seu poderio e do temor que inspirava, é assassinado ao se insurgir contra o governo.

\section{CONSIDERAÇÕES FINAIS}

As figurações da violência no sertão goiano, presentes em $O$ tronco, mostram-se tentaculares e estão intrinsecamente atreladas à vivência do homem sertanejo, ao lugar e ao modo característico em que ele vive, sendo esses elementos que definem como elas se configuram na obra: a população da Vila do Duro é vitimada pelo medo inspirado pelos crimes perpetrados pelos coronéis e por seus jagunços, posto que o contexto histórico e social não lhe permitia outro tipo de vivência se não o de sobreviver à sombra da proteção e das graças do coronel. Não obstante, a polícia também se mostra indigna de confiança, e o próprio coronel é vitimado pela violência que tanto cometera.

Nesse aspecto, as irrupções da violência na obra não apenas se mostram tentaculares, como também adquirem uma feição democrática, para nos valermos de um termo cunhado por Odalia (1983), na medida em que atingem toda a população da Vila do Duro. Não são apenas jagunços e policiais, não são apenas os desafetos do coronel, como Vigilato, Norato e Clemente, que morrem e/ou sofrem com a violência exacerbada no sertão; os coronéis, como já mencionamos, e a população inocente da vila, como a criança Brasica, também não estão imunes às consequências nefastas da brutalidade exacerbada.

Desse modo, no romance analisado, verificamos o retrato de uma população cujas vivências são plasmadas por códigos de conduta que delineiam o que se pode entender como a lei do mais forte, para a qual, elementos como coragem e destemor são tanto condições sine qua non para a irrupção da violência quanto para o estabelecimento de uma certa aura de respeito. Nesse sentido, muitos dos momentos violentos analisados constituem desdobramentos e consequências de ações mediante as quais as personagens tentavam, de alguma forma, se destacar em meio a esse contexto violento, com o objetivo de se mostrarem 
fortes e impassíveis, pretensas qualidades que as tornariam dignas do reconhecimento dos demais.

Notamos ainda que, no contexto narrativo da obra, o retrato da violência está ligado à construção da memória coletiva e individual do homem sertanejo goiano, de modo que seus medos e anseios se constituem e se ressignificam à luz de lembranças de épocas passadas em que abusos e torturas seguidas de morte também haviam se mostrado presentes no sertão. Além disso, ao fim do romance, verifica-se que as memórias, ainda frescas, da última e mais sangrenta batalha da Vila do Duro continuariam vivas por bastante tempo no imaginário de seus moradores.

Por fim, na medida em que o enredo de $O$ tronco aponta para um referente externo, as lembranças retratadas na obra emaranham-se com as lembranças daqueles que presenciaram tais eventos e nele perderam seus entes queridos, os mesmos que assistiram à violência inerente a um sistema coronelista ser suplantada pela brutalidade oriunda de forças policiais, que agiram mais em conformidade com a barbárie e a selvageria do que de acordo com os ditames da lei. Experiências individuais que plasmariam os contornos de uma memória coletiva, qual seja a de um povo que vivenciou uma das páginas mais sangrentas da história de Goiás.

\section{REFERÊNCIAS}

ARENDT, Hannah. Da Violência. Tradução: Maria Claudia Drummond. Ed. Universidade de Brasília, 1985.

BARROSO, Marinalva Nunes. Transcriação narrativa do romance $\boldsymbol{O}$ tronco, de Bernardo Élis, e suas variações discursivas. Dissertação (mestrado). Goiânia: PUC-GO, 2018.

BARTHES, Roland. Introdução à análise estrutural da narrativa. In: BARTHES, Roland et. al. Análise estrutural da narrativa. 7. ed. Tradução de Maria Zélia Barbosa. Petrópolis, RJ: Editora Vozes, 2011. p. 19-62.

CAMPOS, Francisco Itami. Coronelismo em Goiás. Goiânia: Editora da UFG, 1987.

DUTRA E SILVA, Sandro; MOURA, Tálliton Túlio Rocha Leonel de; CAMPOS, Francisco Itami. A terra dos coronéis no Oeste do Brasil: A cattle frontier, violência e dominação fundiária no Cerrado goiano. Topoi, Rio de Janeiro, v. 16, n. 30, p. 234-259, jan./jun. 2015.

ÉLIS, Bernardo. O tronco. In: Obra reunida. v. 2. Rio de Janeiro: José Olympio, 1987

GALTUNG, Johan. Violence, peace, and peace research. Journal of peace research, v. 6, n. 3, p. 167-191, 1969. 
GANCHO, Cândida Vilares. Como analisar narrativas. São Paulo: Ática, 2004.

GINZBURG, Jaime. Literatura, violência e melancolia. Campinas, SP: Autores associados, 2012.

IGNÁCIO, Ewerton de Freitas. Do campo abandonado para a cidade suportada: campo e cidade na literatura brasileira. Anápolis: Universidade Estadual de Goiás, 2010.

JANOTI, Maria de Lourdes Monaco. Coronelismo: uma política de compromissos. 8. ed. São Paulo: Brasiliense, 1992.

LEAL, Victor Nunes. Coronelismo, enxada e voto. 7. ed. São Paulo: Companhia das Letras, 2012.

ODALIA, Nilo. O que é violência. 2. ed. São Paulo: Editora Brasiliense, 1983.

OLIVEIRA, Eliézer Cardoso. Chacinas, combates e massacres: medo e violência em Goiás. Goiânia: PUC-GO; Kelps, 2012.

OLIVEIRA, Eliézer Cardoso; QUADROS, Eduardo Gusmão de. "Um nelore para não sair de uma briga" a cultura da valentia em Goiás. OPSIS, Catalão, v. 15, n. 2, 2015, p. 479-492.

PALACÍN, Luis; MORAES, Maria Augusta de Sant'Anna. História de Goiás. 6. ed. Goiânia: Editora da UCG, 1994.

TOMACHEVSKI, Boris. Temática. In: TOMACHEVSKI, Boris et. al. Teoria da literatura: formalistas russos. Porto Alegre: Globo, 1978. 